\title{
PEG induces maturation of somatic embryos of Passiflora edulis Sims 'UENF Rio Dourado' by differential accumulation of proteins and modulation of endogenous contents of free polyamines
}

\section{Kaliane Zaira Camacho Maximiano Cruz}

Universidade Estadual do Norte Fluminense Darcy Ribeiro

\section{Felipe Astolpho Almeida}

Universidade Estadual do Norte Fluminense Darcy Ribeiro

Ellen Moura Vale

Universidade Estadual do Norte Fluminense Darcy Ribeiro

Nadia Botini

Universidade Estadual do Norte Fluminense Darcy Ribeiro

Rosana Gobbi Vettorazzi

Universidade Estadual do Norte Fluminense Darcy Ribeiro

Renan Carrari Santos

Universidade Estadual do Norte Fluminense Darcy Ribeiro

Claudete Santa-Catarina

Universidade Estadual do Norte Fluminense Darcy Ribeiro

Vanildo Silveira ( $\boldsymbol{\nabla}$ vanildo@uenf.br)

Universidade Estadual do Norte Fluminense Darcy Ribeiro https://orcid.org/0000-0001-5697-6932

\section{Research Article}

Keywords: Passiflora edulis, polyethylene glycol, somatic embryogenesis, proteomics analysis

Posted Date: February 9th, 2022

DOI: https://doi.org/10.21203/rs.3.rs-1287449/v1

License: (c) (i) This work is licensed under a Creative Commons Attribution 4.0 International License.

Read Full License 
Version of Record: A version of this preprint was published at Plant Cell, Tissue and Organ Culture (PCTOC) on April 21st, 2022. See the published version at https://doi.org/10.1007/s11240-022-02301-9. 


\section{Abstract}

Sour passion fruit (Passiflora edulis Sims) has economic and social relevance and is an alternative crop mainly for family farming agriculture. The aim of this work was to evaluate the influence of polyethylene glycol (PEG) on the maturation of somatic embryos associated with differential accumulation of proteins and changes in the endogenous polyamine (PA) content during somatic embryogenesis of $P$. edulis 'UENF Rio Dourado'. Maturation of somatic embryos was performed using embryogenic callus in MS culture medium with PEG $6 \%$ or without PEG (control). PEG $6 \%$ promoted the maturation of a significantly higher number of somatic embryos at globular and cotyledonary stages when compared to the control treatment. The higher somatic embryo formation induced by PEG $6 \%$ was associated with an increase in endogenous contents of free spermine, a PA with an important role in the maturation process of somatic embryogenesis cultures. PEG also promoted a significantly higher content of putrescine and total free PAs at the end of maturation, which was relevant for the increase in the number of somatic embryos. Comparative proteomic analyses of PEG 6\%/control revealed that PEG 6\% treatment induced the upaccumulation of proteins related to the ATP metabolic, glycolytic, generation of precursor metabolite energy, and the response to light stimulus processes. The down-accumulated proteins were related mainly to the cellular metabolic process. The use of PEG induced the maturation and development of somatic embryos of $P$. edulis Sims 'UENF Rio Dourado' by the differential accumulation of proteins and modulation of endogenous contents of PAs.

\section{Introduction}

Sour passion fruit ( $P$. edulis Sims) is present in approximately $90 \%$ of Brazilian orchards (Faleiro et al. 2019) due to its superior qualities in relation to plant health, hybrid vigor and yield of pulp used in the manufacture of juices (Viana et al. 2016). With more than 100 endemic species, passion fruit is considered part of Brazilian biodiversity, presenting high economic and social relevance, with approximately 592.698 tons produced in 2020 (IBGE 2020), serving as an alternative crop mainly for family farming agriculture (Bernacci et al. 2005; Faleiro et al. 2019). P. edulis 'UENF Rio Dourado' is a new sour passion fruit cultivar developed by the UENF plant breeding program that presents climate characteristics north and northwest of Rio de Janeiro (Viana et al. 2016).

Conventional propagation of $P$. edulis occurs via seminiferous (Faleiro et al. 2019). Micropropagation approaches based on in vitro tissue and organ culture of Passiflora species have been developed for scale-up clonal propagation and production of highly phytosanitary plantlets, germplasm conservation, protoplast development, somatic hybridization, genetic transformation and synthetic seed development (Otoni et al. 2013; Ozarowski and Thiem 2013; Faleiro et al. 2019). The first study using in vitro plant cells, tissue and culture with Passiflora was reported by Nakayama (1966) and involved shoot production from stem segments of mature plants of Passiflora caerulea. After some years, somatic embryogenesis studies have also been performed in the Passiflora genus (Otoni et al. 1995; Anthony et al. 1999; Silva et al. 2009; Paim-Pinto et al. 2011; Rosa et al. 2013; Silva et al. 2015; Prudente et al. 2017). 
Somatic embryogenesis is a morphogenetic process analogous to zygotic embryogenesis, in which single cells or a small group of somatic cells act as precursors of embryos (Tautorus et al. 1991). The developmental stages of somatic and zygotic embryos are similar; however, in contrast to zygotic embryogenesis, somatic embryogenesis allows embryo differentiation from a diverse set of somatic tissues (Dodeman et al. 1997).

The normal development and maturation of somatic embryos can be considered one of the main bottlenecks that limits the commercial application of somatic embryogenesis (Márquez-Martín et al. 2011; Mishra et al. 2012; Vale et al. 2014) because during the maturation phase, somatic embryos undergo morphological and biochemical changes, such as storage compound deposition (MárquezMartín et al. 2011), synthesis and mobilization of proteins, carbohydrates and lipids, and alteration of endogenous contents of polyamines (PAs) (Silveira et al. 2004). Polyethylene glycol (PEG) has been used to promote maturation in somatic embryogenesis in various species, including Phoenix dactylifera (Alkhateeb 2006), Carica papaya (Vale et al. 2014; Almeida et al. 2019; Botini et al. 2021), Pinus (Stasolla and Yeung 2003; Salo et al. 2016), and Cicer arietinum (Mishra et al. 2012). PEG induces water stress once this high-molecular-weight molecule is not able to pass through the cell wall, which leads to restricted water absorption, low turgor pressure and a reduction in the intracellular osmotic potential (Mishra et al. 2012), simulating the desiccation step during somatic embryogenesis (Vale et al. 2014).

The osmotic stress induced by PEG can alter the endogenous contents of some compounds, such as proteins and PAs. Thus, studies that investigate the physiological, biochemical and molecular aspects associated with the competence and development of embryonic cells offer a strong potential to identify important molecules that can be used to monitor the development of somatic embryos and improve the understanding regarding the particularities of the process of somatic embryogenesis (Heringer et al. 2018). PAs have been reported to act in many processes during cell proliferation and differentiation, including embryogenesis (Pal Bais and Ravishankar 2002; Silveira et al. 2004). PAs have been studied mainly as important routes for plant regeneration and as a potential model system for studying regulatory events of in vitro plant morphogenesis (Yadav and Rajam 1997).

More recently, attention has turned to revealing the differential regulation of proteins associated with somatic embryogenesis development (Aguilar-Hernández and Loyola-Vargas 2018; Heringer et al. 2018). Proteomics approaches have been considered a powerful tool for examining the physiological and biochemical conditions of plant tissues and organs. The differentially regulated proteins during the developmental stages of somatic embryos are closely related to various cellular processes, such as cell division, cell wall modifications and defense response (Kumaravel et al. 2020). Thus, identifying the differentially accumulated proteins associated with the maturation process has become an important strategy for understanding the molecular mechanisms related to somatic embryo development and identifying new biomarker candidates that could be used to develop strategies to improve somatic embryogenesis protocols (Isah 2019; Kumaravel et al. 2020; Botini et al. 2021). The aim of this work was to evaluate the influence of polyethylene glycol (PEG) on the maturation of somatic embryos associated 
with the differential accumulation of proteins and changes in the endogenous polyamine (PA) content during somatic embryogenesis of $P$. edulis 'UENF Rio Dourado'.

\section{Materials And Methods}

\section{Plant material and induction of somatic embryogenesis}

Mature seeds of $P$. edulis 'UENF Rio Dourado' were obtained from the collection of ripe fruits at the UENF Experimental orchard $\left(21^{\circ} 40^{\prime} \mathrm{S}, 42^{\circ} 04^{\prime} \mathrm{W}\right.$, altitude of $\left.76 \mathrm{~m}\right)$. The outer integuments of seeds were removed with the help of mini-vise as described by Silva et al. (2009), and the seeds without the outer integuments were disinfested in a laminar flow chamber by immersion in 70\% ethanol (Sigma-Aldrich, St. Louis, USA) for $1 \mathrm{~min}$, followed by immersion in $30 \%$ commercial bleach (sodium hypochlorite from 0.6 to $0.75 \%$; Qboa ${ }^{\circledR}$ Anhembi SA, Osasco, Brazil) supplemented with two drops of Tween ${ }^{\circledR} 20$ (SigmaAldrich) for $30 \mathrm{~min}$, followed by three rinses with distilled and autoclaved water. After the final rinse, the seeds were kept overnight in sterile distilled water to rehydrate and to facilitate zygotic embryo removal according to Silva et al. (2009).

The zygotic embryos were aseptically removed from the seeds in a laminar flow chamber and transferred into Petri dishes (90 mm x $15 \mathrm{~mm}$ ) containing MS (Murashige and Skoog 1962) culture medium (Phytotechnology Lab, Overland Park, USA) supplemented with $100 \mathrm{mg} \mathrm{L}^{-1}$ myo-inositol (SigmaAldrich), $30 \mathrm{~g} \mathrm{~L}^{-1}$ sucrose (Sigma-Aldrich), $20 \mu \mathrm{M}$ 2,4-dichlorophenoxyacetic acid (2,4-D) (SigmaAldrich), $5 \mu \mathrm{M}$ 6-benziladenina (BA) (Sigma-Aldrich), and $2 \mathrm{~g} \mathrm{~L}^{-1}$ Phytagel ${ }^{\circledR}$ (Sigma-Aldrich). The pH of the culture medium was adjusted to 5.7 before Phytagel $\circledast$ was added and autoclaved at $121^{\circ} \mathrm{C}$ for 15 minutes. The Petri dishes containing the zygotic embryos were kept in a growth chamber at a temperature of $25^{\circ} \mathrm{C} \pm 1$ and in the dark for 45 days.

After 45 days, the embryogenic callus was separated by a friable yellowish callus appearance (Campos et al. 2017). Aiming at multiplication, the embryogenic calli were transferred to new culture medium by three consecutive subcultures with 21 days between each under the same conditions and culture medium.

\section{Maturation experiment}

Three embryogenic calli (300 mg of fresh matter-FM- each) were inoculated into Petri dishes (90 mm x 15 $\mathrm{mm}$ ) containing $20 \mathrm{~mL}$ of MS culture medium supplemented with $30 \mathrm{~g} \mathrm{~L}^{-1}$ sucrose, $2 \mathrm{~g} \mathrm{~L}^{-1}$ Phytagel, 100 $\mathrm{mg} \mathrm{L}^{-1}$ myo-inositol, and without (control) or with $6 \%$ PEG. The experiment was carried out with seven biological replicates, with each being a Petri dish with three embryogenic calli. The cultures were kept in the growth room at $25^{\circ} \mathrm{C} \pm 1$ in the dark for seven days. Thereafter, the cultures were grown at a temperature of $25 \pm 1^{\circ} \mathrm{C}$, and a 16-h photoperiod was established with GreenPower TLED 20-W W $\mathrm{m}^{B}$ (Koninklijke Philips Electronics NV, Amsterdam, Netherlands) at $55 \mu \mathrm{mol} \mathrm{m}{ }^{-2} \mathrm{~s}^{-1}$ for up to 28 days of culture. 
The experiment was performed using a completely randomized design. The number of somatic embryos at the globular and cotyledonary stages was evaluated at 14 and 28 days of maturation from seven biological replicates. Samples from PEG 6\% treatment were collected at 14 days of maturation for histomorphological analyses. Samples from both the control and PEG 6\% treatments were collected at 14 days of maturation for proteomic analyses. For PA determination, samples at 14 and 28 days in both treatments were collected. For PA and proteomic analysis, samples were frozen in liquid nitrogen and stored at $-80^{\circ} \mathrm{C}$ until analysis.

\section{Histomorphological analysis}

Embryogenic calli from PEG 6\% treatment at 14 days of maturation were fixed in fixative solution containing 2.5\% glutaraldehyde (Sigma-Aldrich) and $4 \%$ formaldehyde (Sigma-Aldrich) diluted in $0.1 \mathrm{M}$ sodium cacodylate buffer (Merck Millipore, Darmstadt, Germany) pH 7.2 at room temperature for $48 \mathrm{~h}$. Samples were dehydrated with an increasing ethanolic series (30, 50, 70, 90 and 100\%) twice for $12 \mathrm{~h}$ each. Subsequently, the samples were infiltrated in 1:1 (v/v) historesin ${ }^{\circledR}$ (Leica, Heidelberger, Germany) and $100 \%$ ethanol (Merck Millipore) for $24 \mathrm{~h}$, followed by $100 \%$ historesin for $48 \mathrm{~h}$, and hardened in 100\% historesin. Sections ( $5 \mu \mathrm{m}$ ) were obtained on a Leica microtome (Leica), mounted on slides (Sail Brand, Zhejiang, China) and then stained with $1 \%$ aqueous toluidine blue solution (Sigma-Aldrich). The sections were observed in an Axiolmager M2 microscope (Carl Zeiss ${ }^{\circledR}$, Jena, Germany) with the AxioVision 4.8 program (Carl Zeiss). Images were obtained with an AxioCam MR3 camera (Carl Zeiss) coupled to the equipment.

\section{Free polyamine (PA) determination}

Free PA determination was performed according to Santa-Catarina et al. (2006). For PA extraction, samples were homogenized with $1.2 \mathrm{~mL}$ of $5 \%$ perchloric acid (PCA; Merck Millipore), incubated at $4^{\circ} \mathrm{C}$ for $1 \mathrm{~h}$ and centrifuged for $20 \mathrm{~min}$ at $16,000 \times g$ and $4^{\circ} \mathrm{C}$. The supernatants were collected, and free PAs in the supernatant were analyzed directly by derivatization with dansyl chloride (Merck Millipore) and

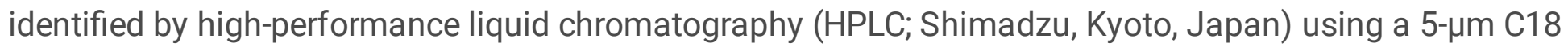
reverse-phase column (Shin-pack CLC ODS, Shimadzu). The column gradient was achieved by adding increasing volumes of acetonitrile (Merck Millipore) to a $10 \%$ aqueous acetonitrile solution with the $\mathrm{pH}$ adjusted to 3.5 with hydrochloric acid (Merck Millipore). The acetonitrile concentration was maintained at $65 \%$ for the first $10 \mathrm{~min}$, increased from 65 to $100 \%$ between 10 and $13 \mathrm{~min}$, and maintained at $100 \%$ between 13 and $21 \mathrm{~min}$ at a flow rate of $1 \mathrm{~mL} \mathrm{~min}^{-1}$ and $40^{\circ} \mathrm{C}$. The PA concentration was determined using a fluorescence detector at $340 \mathrm{~nm}$ excitation and $510 \mathrm{~nm}$ emission. The peak areas and retention times of the samples were measured through comparisons with PA standards putrescine (Put), spermidine (Spd) and spermine (Spm) (Sigma-Aldrich).

\section{Proteomic analysis}

Samples of embryogenic callus at 14 days of maturation for both Control and PEG $6 \%$ treatments (three biological replicates, $300 \mathrm{mg}$ of FM per sample) were macerated in a mortar and pestle using liquid nitrogen. The samples were transferred to microtubes with $1 \mathrm{~mL}$ of extraction buffer, vortexed for 5 min 
and incubated on ice for $30 \mathrm{~min}$. The extraction buffer consisted of $7 \mathrm{M}$ urea (GE Healthcare, Piscataway, USA), $2 \mathrm{M}$ thiourea (GE Healthcare), 2\% Triton X-100 (GE Healthcare), 1\% dithiothreitol (DTT, GE Healthcare), and $1 \mathrm{mM}$ phenylmethanesulfonylfluoride (PMSF, Sigma-Aldrich). Samples were vortexed for $30 \mathrm{~min}$ at $8^{\circ} \mathrm{C}$ and centrifuged at $16,000 \times g$ for $20 \mathrm{~min}$ at $4^{\circ} \mathrm{C}$. The supernatants were collected, and the protein concentration was measured using a 2-D Quant Kit (GE Healthcare).

Before the trypsin digestion step, protein samples were precipitated using the methanol/chloroform methodology to remove any interferent from the samples (Nanjo et al. 2012). After protein precipitation, samples were resuspended in $7 \mathrm{M}$ urea/2 $\mathrm{M}$ thiourea solution for proper resuspension. Protein digestion of aliquots of $100 \mu \mathrm{g}$ protein from each biological replicate was performed using the filter-aided sample preparation (FASP) method as described by Wisniewski et al. (2009) with modifications performed by Reis et al. (2021). The resulting peptides were quantified by the $A_{205} \mathrm{~nm}$ protein and peptide methodology using a NanoDrop 2000c spectrophotometer (Thermo Fisher Scientific, Waltham, USA).

\section{Analysis by mass spectrometry}

Mass spectrometry was performed using a nanoAcquity UPLC connected to a Q-TOF SYNAPT G2-Si instrument (Waters, Manchester, UK). Runs consisted of three biological replicates of $1 \mu \mathrm{g}$ of digested proteins. During separation, samples were loaded onto the nanoAcquity UPLC M-Class Symmetry C18 5 $\mu \mathrm{m}$ trap column (100 $, 5 \mu \mathrm{m}, 180 \mu \mathrm{m} \times 20 \mathrm{~mm}, 2 \mathrm{D}$; Waters) at $5 \mu \mathrm{L} \mathrm{min}^{-1}$ for $3 \mathrm{~min}$ and then onto the nanoAcquity M-Class HSS T3 $1.8 \mu \mathrm{m}$ analytical reversed-phase column (100 $, 1.8 \mu \mathrm{m}, 75 \mu \mathrm{m} \times 150 \mathrm{~mm}$; Waters) at $400 \mathrm{~nL} \mathrm{~min}^{-1}$, with a column temperature of $45^{\circ} \mathrm{C}$. For peptide elution, a binary gradient was used, with mobile phase A consisting of water (Tedia; Fairfield, USA) and 0.1\% formic acid (SigmaAldrich) and mobile phase B consisting of acetonitrile (Sigma-Aldrich) and $0.1 \%$ formic acid. Gradient elution started at $5 \%$ B, then ramped from $5 \%$ B to $40 \%$ B up to 91.12 min, and from $40 \%$ B to $99 \%$ B until $95.12 \mathrm{~min}$, being maintained at $99 \%$ until $99.12 \mathrm{~min}$, then decreasing to $5 \% \mathrm{~B}$ until $101.12 \mathrm{~min}$, and kept $5 \% \mathrm{~B}$ until the end of experiment at 117.00 min. Mass spectrometry was performed in positive and resolution mode ( $V$ mode), 35,000 FWHM, with ion mobility $\left(\mathrm{HDMS}^{\mathrm{E}}\right)$, and in DIA mode; ion mobility separation used an IMS wave velocity ramp starting with $800 \mathrm{~m} \mathrm{~s}^{-1}$ and ending with $500 \mathrm{~m} \mathrm{~s}^{-1}$; the transfer collision energy ramped from $25 \mathrm{~V}$ to $55 \mathrm{~V}$ in high-energy mode; cone and capillary voltages of $30 \mathrm{~V}$ and $3000 \mathrm{~V}$, respectively; nano flow gas of $0.5 \mathrm{Bar}$ and purge gas of $150 \mathrm{~L} \mathrm{~h}^{-1}$; and a source temperature of $100^{\circ} \mathrm{C}$. For the TOF parameters, the scan time was set to $0.6 \mathrm{~s}$ in continuum mode with a

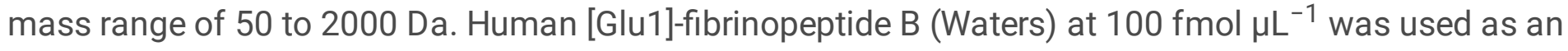
external calibrant, and lock mass acquisition was performed every $30 \mathrm{~s}$. Mass spectra acquisition was performed by MassLynx v 4.1 software.

\section{Proteomics data analysis}

Spectral processing and database searching were performed using ProteinLynx Global Server (PLGS; version 3.0.2) (Waters) and the ISOQuant software workflow (Distler et al. 2014a; Distler et al. 2016). The PLGS was processed using a low-energy threshold of 150 (counts), an elevated energy threshold of 50, and an intensity threshold of 750. In addition, the analysis was performed using the following 
parameters: two missed cleavages, a minimum fragment ion per peptide equal to 3 , a minimum fragment ion per protein equal to 7 , a minimum peptide per protein equal to 2 , fixed modifications of carbamidomethyl and variable modifications of oxidation and phosphoryl. The false discovery rate (FDR) for peptide and protein identification was set to a maximum of $1 \%$, with a minimum peptide length of six amino acids. The proteomics data were processed against Glycine max (ID: UP000008827) from UniProtKB.

Comparative label-free quantification analyses were performed using ISOQuant software v.1.7 using previously described settings and algorithms (Distler et al. 2014a; Distler et al. 2016). The protein identification parameters in ISOQuant were set to an FDR of 1\%, a peptide score greater than six, a minimum peptide length of six amino acids, and at least two peptides per protein. Label-free quantification was estimated using the TOP3 quantification approach (Silva et al. 2006). This is followed by the multidimensional normalization process implemented within ISOQuant (Distler et al. 2014b). To ensure the quality of the results after data processing, only proteins present or absent (for unique proteins) in all biological replicates were considered for differential accumulation analysis in the PEG $6 \% /$ Control comparison. Proteins with significant Student's t test (two-tailed; $P<0.05$ ) results were considered differentially accumulated (DAP), as up-accumulated if the $\log _{2}$ fold change (FC) was greater than 0.6 and down-accumulated if the $\log _{2}$ FC was less than -0.6. The proteomics MS data have been deposited in the ProteomeXchange Consortium via the PRIDE (Perez-Riverol et al. 2019) partner repository with the dataset identifier PXD031175.

Finally, proteins were submitted to functional characterization by OmicsBox software (BioBam Bioinformatics S.L., Valencia, Spain). Sequences with biological processes not identified by OmicsBox were manually complemented with the online BLAST tools UniProtKB and NCBI. The predicted interaction networks of DAPs were constructed using Arabidopsis thaliana homologs that were identified through a STRING search followed by downstream analysis in Cytoscape (version 3.9) (Shannon et al. 2003). The gene IDs referring to the regulated proteins in each treatment were used as reference set entries for the enrichment analysis. The hypergeometric test with Bonferroni step down correction was used to assess enrichment categories in the Gene Ontology (GO) domains 'Biological process' from the $A$. thaliana database. In the resultant graph, the functional grouping was evaluated with \#Genes/Term using the kappa statistic. Pairs of terms (nodes) with a kappa value of at least 0.5 related to edges in the network.

\section{Statistical analysis}

All experiments were performed using a completely randomized design. The data were analyzed using analysis of variance (ANOVA) $(p<0.05)$ followed by the Student-Newman-Keuls (SNK) test using the R software environment ( $R$ Core Team 2014).

\section{Results}

\section{Effect of PEG on the maturation of somatic embryos}


A significant effect of PEG 6\% was observed regarding the maturation of somatic embryos of $P$. edulis 'UENF Rio Dourado' after 28 days of incubation (Table 1; Fig. 1). The embryogenic callus incubated under PEG 6\% treatment showed a significantly higher number of somatic embryos at the globular and cotyledonary stages compared to embryogenic callus in the control treatment at both 14 and 28 days of incubation (Table 1).

Table 1

Number of somatic embryos (per Petri dish) of $P$. edulis 'UENF Rio Dourado' at the globular and cotyledonary stages from embryogenic callus matured under the control and PEG 6\% treatments.

\begin{tabular}{|c|c|c|c|c|}
\hline \multirow[t]{3}{*}{ Somatic embryo developmental stage } & \multicolumn{4}{|l|}{ PEG } \\
\hline & \multicolumn{2}{|c|}{$0 \%$ (control) } & \multicolumn{2}{|l|}{$6 \%$} \\
\hline & Day 14 & Day 28 & Day 14 & Day 28 \\
\hline Globular & $6.9 \mathrm{Bb}$ & 19.7 Ba & $20.6 \mathrm{Ab}$ & $45.1 \mathrm{Aa}$ \\
\hline Cotyledonary & $0.0 \mathrm{Ab}$ & $20.7 \mathrm{Ba}$ & $3.3 \mathrm{Ab}$ & 33.7 Aa \\
\hline \multicolumn{5}{|c|}{$\begin{array}{l}{ }^{*} \text { Capital letters denote significant differences between the maturation treatments at the same time of } \\
\text { incubation. Lowercase letters denote significant differences between the time of incubation within the } \\
\text { same maturation treatment. Means followed by different letters are significantly different according } \\
\text { to the Student-Newman-Keuls (SNK) test }(p<0.05) \text {. ( } n=7 ; \text { CV Globular }=19.35 \% \text {; CV Cotyledonary }= \\
38.53 \%) \text {. }\end{array}$} \\
\hline
\end{tabular}

Morphologically, embryogenic callus treated with PEG 6\% (Fig. 1D-E) presented a more compact aspect than embryogenic callus in the control treatment (Fig. 1B-C) during the time of incubation. The embryogenic callus showed somatic embryo differentiation on the callus surface, as the globular (Fig. 1F) and cotyledonary (Fig. 1G) stages were observed.

\section{Histomorphological aspects of embryogenic callus under PEG in the maturation of somatic embryos}

Embryogenic callus of $P$. edulis at 14 days of maturation is composed of different portions of tissues (Fig. 2A) with a more compact appearance, yellowish color and a structure more organized (Fig. 2B), and some parts of the callus are less compact, with spongy appearance or soft mass with translucent aspect (Fig. 2C). The histomorphological analyses showed that the compact embryogenic callus was composed of meristematic-type cells (MC) with small and isodiametric cells, prominent nuclei and dense cytoplasm (Fig. 2D). The soft mass of the callus showed nonmeristematic-type cells (NMC), which were larger and elongated cells and highly vacuolated (Fig. 2D).

The development of somatic embryos occurs from the MC portion of the embryogenic callus of $P$. edulis. At 14 days of maturation, the embryogenic callus allowed us to observe the formation of somatic 
embryos at earlier stages of development, mainly in the periphery of the callus (Fig. 2E), observing the presence of globular (Fig. 2F) and heart somatic embryos (Fig. 2G).

\section{PEG 6\% induces changes in endogenous contents of polyamines (PAs) during maturation of somatic embryos}

The contents of free PAs (Fig. 3) were affected by the maturation treatments (PEG 6\% or control) and during incubation. Embryogenic callus incubated in PEG 6\% presented significantly higher levels of total free PAs (Fig. 3A) and free Put (Fig. 3B) at 28 days of culture than those incubated in the control treatment. In addition, PEG 6\% induced a significantly higher content of Spm (Fig. 3C) in embryogenic callus compared to those incubated in the control treatment at both incubation times. The levels of endogenous Spd showed no significant changes (Fig. 3D).

\section{PEG 6\% induces a differential accumulation of proteins during the maturation of somatic embryos}

The comparative proteomics analysis of embryogenic callus at 14 days of maturation allowed the identification of a total of 514 proteins (Supplementary Table 1). The comparison between embryogenic callus matured under PEG 6\% with those from the control treatment (PEG 6\%/control comparison) revealed 51 differentially accumulated proteins (DAPs), with 15 up- and 20 down-accumulated, 14 proteins unique to PEG $6 \%$ and two proteins unique to the control (Table 2). 
Table 2

Differentially accumulated proteins (DAPs) in the embryogenic callus of $P$. edulis 'UENF Rio Dourado' at 14 days of maturation under PEG 6\% treatment compared with the control treatment (without PEG).

$\begin{array}{lll}\text { Acession Description } & \text { Arabidopsis Biological Process } \\ \text { ortholog } \\ \text { (STRING } \\ \text { Mapping) }\end{array}$

\section{UP- ACCUMULATED}

$\begin{array}{lll}\text { I1L3K7 Enolase } & \text { ENO1 } & \begin{array}{l}\text { ATP metabolic process, } \\ \text { Glycolytic process, } \\ \text { Carbohydrate metabolic } \\ \text { process }\end{array} \\ & \end{array}$

I1M6E1 Heat shock cognate protein $80 \quad$ HSP81-3 Protein folding, Response to temperature stimulus, cellular process

\begin{tabular}{|c|c|c|c|}
\hline I1MM44 & $\begin{array}{l}\text { Glyceraldehyde-3-phosphate } \\
\text { dehydrogenase GAPCP1, } \\
\text { chloroplastic }\end{array}$ & GAPCP-1 & $\begin{array}{l}\text { ATP metabolic process, } \\
\text { Glycolytic process, Carbon } \\
\text { fixation in photosynthetic } \\
\text { organisms, carbohydrate } \\
\text { metabolic process }\end{array}$ \\
\hline
\end{tabular}

I1N6I4 6-phosphogluconate dehydrogenase, decarboxylating 3

AT3G02360 Generation of precursor and isoform A metabolites energy, Carbohydrate metabolic process, Phosphatecontaining compound metabolic process

\begin{tabular}{|llll} 
A0A0R0EWS1 & Ubiquitin-activating enzyme E1 1 & UBA1 & $\begin{array}{l}\text { Response to metal ion, } \\
\text { cellular metabolic process, } \\
\text { response to cadmium ion }\end{array}$ \\
\hline I1LK56 & $\begin{array}{l}\text { Ras-related protein RABE1c-like } \\
\text { isoform X2 }\end{array}$ & AT5G59840 & $\begin{array}{l}\text { Generation of precursor and } \\
\text { metabolites energy, } \\
\text { Carbohydrate metabolic } \\
\text { process }\end{array}$ \\
\hline I1LCM5 & $\begin{array}{l}\text { Malate dehydrogenase [NADP], } \\
\text { chloroplastic }\end{array}$ & AT5G58330 & $\begin{array}{l}\text { Generation of precursor and } \\
\text { metabolites energy, } \\
\text { Carbohydrate metabolic } \\
\text { process }\end{array}$ \\
\hline
\end{tabular}

\begin{tabular}{|c|c|c|c|}
\hline I1NBU8 & $\begin{array}{l}\text { Putative } \\
\text { pectinesterase/pectinesterase } \\
\text { inhibitor } 41\end{array}$ & AT2G47550 & Cell wall modification \\
\hline
\end{tabular}

\begin{tabular}{|llll|}
\hline Q2PMV0 & ATP synthase CF1 beta subunit & ATPB(PB) & ATP metabolic process \\
\hline Q43468 & HSP70-HSP90 organizing protein 1 & HOP2 & $\begin{array}{l}\text { Protein folding, Stress } \\
\text { response }\end{array}$ \\
\hline A5JVZ7 & $\begin{array}{l}\text { Superoxide dismutase [Mn], } \\
\text { mitochondrial }\end{array}$ & MSD1 & $\begin{array}{l}\text { Response to metal ion, } \\
\text { cellular metabolic process }\end{array}$ \\
\hline
\end{tabular}




\begin{tabular}{|c|c|c|c|}
\hline Acession & Description & $\begin{array}{l}\text { Arabidopsis } \\
\text { ortholog } \\
\text { (STRING } \\
\text { Mapping) }\end{array}$ & Biological Process \\
\hline A0A0R4J318 & $\begin{array}{l}\text { Peptidyl-prolyl cis-trans isomerase } \\
\text { CYP19-3 }\end{array}$ & ROC2 & $\begin{array}{l}\text { Response to metal ion, } \\
\text { Protein folding, cellular } \\
\text { metabolic process }\end{array}$ \\
\hline K7M8F8 & $\begin{array}{l}\text { Probable fructokinase-6, } \\
\text { chloroplastic }\end{array}$ & AT1G66430 & $\begin{array}{l}\text { Cellular metabolic process, } \\
\text { Carbohydrate metabolic } \\
\text { process, phosphate-- } \\
\text { containing compound } \\
\text { metabolic process }\end{array}$ \\
\hline I1MQM4 & Glutamate decarboxylase & GAD5 & $\begin{array}{l}\text { Glutamate metabolic } \\
\text { process }\end{array}$ \\
\hline AOAOROJER2 & $\begin{array}{l}\text { Peptidyl-prolyl cis-trans isomerase } \\
\text { CYP40-like }\end{array}$ & SQN & $\begin{array}{l}\text { Protein folding, cellular } \\
\text { metabolic process }\end{array}$ \\
\hline \multicolumn{4}{|c|}{ DOWN-ACCUMULATED } \\
\hline P54774 & $\begin{array}{l}\text { Cell division cycle protein } 48 \\
\text { homolog }\end{array}$ & ATCDC48B & Cellular metabolic process \\
\hline I1LXY2 & $\begin{array}{l}\text { 5- } \\
\text { methyltetrahydropteroyltriglutamate- } \\
\text {-homocysteine methyltransferase }\end{array}$ & ATMS1 & $\begin{array}{l}\text { Amino-acid biosynthesis } \\
\text { Methionine biosynthesis }\end{array}$ \\
\hline AOAOROFY49 & Heat shock 70 kda protein & HSP70b & Protein folding \\
\hline A0A0R0K398 & $\begin{array}{l}\text { Guanosine nucleotide diphosphate } \\
\text { dissociation inhibitor } 2\end{array}$ & GDI2 & $\begin{array}{l}\text { Protein transport, Small } \\
\text { GTPase mediated signal } \\
\text { transduction }\end{array}$ \\
\hline I1J7T0 & Pectinesterase 2 & AT2G45220 & $\begin{array}{l}\text { Cell wall modification,Pectin } \\
\text { catabolic process }\end{array}$ \\
\hline I1LWR5 & UDP-glucose 6-dehydrogenase 1 & UGD2 & Cellular metabolic process \\
\hline I1J5Y9 & UDP-glucose 6-dehydrogenase 4 & UGD2 & Cellular metabolic process \\
\hline I1J4J8 & NADP-dependent malic enzyme & NADP-ME4 & $\begin{array}{l}\text { Cellular metabolic process, } \\
\text { Malate metabolic process, } \\
\text { Pyruvate metabolic process }\end{array}$ \\
\hline Q6Q2Z8 & Phosphoenolpyruvate carboxylase 2 & PPC1 & $\begin{array}{l}\text { Cellular metabolic process, } \\
\text { Carbon fixation, } \\
\text { Tricarboxylic acid cycle }\end{array}$ \\
\hline I1JTY8 & Aminopeptidase M1 isoform X2 & APM1 & Proteolysis \\
\hline AOAOR0G163 & Sucrose synthase 2 isoform $\mathrm{X} 2$ & SSA & $\begin{array}{l}\text { Cellular metabolic process, } \\
\text { Sucrose metabolic process }\end{array}$ \\
\hline I1LWI3 & $\begin{array}{l}\text { Hypersensitive-induced response } \\
\text { protein-like protein } 2\end{array}$ & AT1G69840 & Unknow (Binding) \\
\hline
\end{tabular}




\begin{tabular}{|c|c|c|c|}
\hline Acession & Description & $\begin{array}{l}\text { Arabidopsis } \\
\text { ortholog } \\
\text { (STRING } \\
\text { Mapping) }\end{array}$ & Biological Process \\
\hline I1KSD7 & $\begin{array}{l}\text { Mitochondrial } \\
\text { dicarboxylate/tricarboxylate } \\
\text { transp.DTC }\end{array}$ & AT5G19760 & Transport \\
\hline I1KV07 & $\begin{array}{l}\text { ATP-dependent 6- } \\
\text { phosphofructokinase } 3\end{array}$ & PFK3 & $\begin{array}{l}\text { Cellular metabolic process, } \\
\text { Gycolysis }\end{array}$ \\
\hline I1JYA9 & $\begin{array}{l}\text { Superoxide dismutase [Mn], } \\
\text { mitochondrial }\end{array}$ & MSD1 & $\begin{array}{l}\text { Response to metal ion, } \\
\text { cellular metabolic process }\end{array}$ \\
\hline 11JHT1 & Glutamate decarboxylase 1 & GAD & $\begin{array}{l}\text { Response to metal ion, } \\
\text { Cellular metabolic process }\end{array}$ \\
\hline A0A0R4J656 & Chaperonin CPN60-2, mitochondrial & HSP60 & $\begin{array}{l}\text { Response to metal ion, } \\
\text { Cellular metabolic process }\end{array}$ \\
\hline Q5F2M9 & Glutamate dehydrogenase 1 & GDH1 & $\begin{array}{l}\text { Response to metal ion, } \\
\text { Cellular metabolic process }\end{array}$ \\
\hline I1LQD7 & Fructokinase-2 isoform B & AT3G59480 & Cellular metabolic process \\
\hline A0AOROFCD2 & Elongation factor Tu, chloroplastic & RABE1b & Cellular metabolic process \\
\hline \multicolumn{4}{|c|}{ UNIQUE PEG 6\% } \\
\hline D4N5G3 & $\begin{array}{l}\text { Ribulose bisphosphate } \\
\text { carboxylase/oxygenase activase, } \\
\text { chloroplastic }\end{array}$ & RCA & $\begin{array}{l}\text { Response to temperature } \\
\text { stimulus, Response to light } \\
\text { stimulus }\end{array}$ \\
\hline A0A368UHG1 & $\begin{array}{l}\text { Triosephosphate isomerase, } \\
\text { cytosolic }\end{array}$ & TPI & $\begin{array}{l}\text { ATP metabolic process, } \\
\text { Generation of precursor } \\
\text { metabolites and energy, } \\
\text { Glycolityc process }\end{array}$ \\
\hline I1LZ47 & $60 S$ ribosomal protein L12 & AT2G37190 & $\begin{array}{l}\text { Cellular metabolic process, } \\
\text { Response to temperature } \\
\text { stimulus }\end{array}$ \\
\hline I1KPN3 & Luminal-binding protein 5 & BIP2 & $\begin{array}{l}\text { Response to metal ion, } \\
\text { Protein folding, Cellular } \\
\text { metabolic process }\end{array}$ \\
\hline P09755 & $\begin{array}{l}\text { Chlorophyll a-b binding protein } 21 \text {, } \\
\text { chloroplastic }\end{array}$ & LHB1B1 & $\begin{array}{l}\text { Photosynthesis, light } \\
\text { harvesting in photosystem I, } \\
\text { response to light stimulus }\end{array}$ \\
\hline K7KXN7 & Tubulin alpha-3 chain-like & TUA5 & $\begin{array}{l}\text { Cellular process, } \\
\text { Microtubule-based process }\end{array}$ \\
\hline K7LWG5 & 14-3-3-like protein $\mathrm{D}$ isoform $\mathrm{X} 1$ & AT2G42590 & Protein DNA binding \\
\hline I1L0D6 & Berberine bridge enzyme-like 21 & AT4G20840 & Oxidative stress \\
\hline
\end{tabular}




\begin{tabular}{|c|c|c|c|}
\hline Acession & Description & $\begin{array}{l}\text { Arabidopsis } \\
\text { ortholog } \\
\text { (STRING } \\
\text { Mapping) }\end{array}$ & Biological Process \\
\hline $11 \mathrm{~J} 8 \mathrm{W0}$ & $\begin{array}{l}\text { Succinate dehydrogenase } \\
\text { [ubiquinone] flavoprotein subunit } 1, \\
\text { mitochondrial }\end{array}$ & SDH1-1 & $\begin{array}{l}\text { ATP metabolic process, } \\
\text { Generation of precursor } \\
\text { metabolites energy, } \\
\text { Phosphate-containing } \\
\text { compound metabolic } \\
\text { process }\end{array}$ \\
\hline I1N1B9 & $\begin{array}{l}\text { Pyruvate dehydrogenase E1 } \\
\text { component subunit alpha, } \\
\text { mitochondrial }\end{array}$ & IAR4 & $\begin{array}{l}\text { ATP metabolic process, } \\
\text { Generation of precursor } \\
\text { metabolites and energy, } \\
\text { Glycolytic process, } \\
\text { Carbohydrate metabolic } \\
\text { process }\end{array}$ \\
\hline I1LOH7 & Berberine bridge enzyme-like 21 & AT4G20840 & Oxidative stress. \\
\hline I1KMW7 & $\begin{array}{l}\text { Pectinesterase/pectinesterase } \\
\text { inhibitor }\end{array}$ & AT5G27870 & $\begin{array}{l}\text { Cell wall modification, Pectin } \\
\text { catabolic process. }\end{array}$ \\
\hline I1LAL4 & Chaperonin CPN60-2, mitochondrial & HSP60 & $\begin{array}{l}\text { Protein folding, Cellular } \\
\text { metabolic process, } \\
\text { Response to cadmium ion }\end{array}$ \\
\hline Q43467 & Elongation factor Tu, chloroplastic & RABE1b & Cellular metabolic process \\
\hline \multicolumn{4}{|c|}{ UNIQUE CONTROL } \\
\hline AOA0R0GAY5 & Peroxidase 16 & AT2G18980 & Response to oxidative stress \\
\hline AOAOROH9T5 & Peptidyl-prolyl cis-trans isomerase & ROC3 & Protein folding \\
\hline
\end{tabular}

Considering the DAPs during the maturation of embryogenic callus at 14 days under PEG $6 \% /$ control, some proteins related to somatic embryogenesis development were up-accumulated, such as enolase (ENO1; I1L3K7), heat shock cognate protein 80 (HSP81-3; 11 M6E1), glyceraldehyde-3-phosphate dehydrogenase GAPCP1, chloroplastic (GAPCP-1; 11MM44), 6-phosphogluconate dehydrogenase, decarboxylating 3 isoform A (AT3G02360; I1 N6I4), superoxide dismutase [Mn], mitochondrial (MSD1; A5JVZ7), ubiquitin-activtin enzyme E1 1 (UBA1; A0AOR0EWS1), peptidyl-prolyl cis-trans isomerase CYP19-3 (ROC2; A0A0R4J318), ras-related protein RABE1 c-like (AT5G59840; I1LK56), probable fructokinase-6, chloroplastic (AT1G66430; K7M8F8), glutamate decarboxylase (GAD5; I1MQM4), malate dehydrogenase [NADP], chloroplastic (11LCM5; AT5G58330), putative pectinesterase/pectinesterase inhibitor 41 (AT2G47550; I1 NBU8), ATP synthase CF1 beta subunit (ATPB; Q2PMV0) and and, HSP70HSP90 organizing protein 1 (HOP2, Q43468) (Table 2).

Additionally, unique proteins in PEG 6\%, related to somatic embryogenesis development, were observed, such as ribulose biphosphate carboxylase/oxygenase activase, chloroplastic (RCA; D4N5G3), triosephosphate isomerase, cytosolic (TPI; A0A368UHG1), 60S ribosomal protein L12 (AT2G37190; 11LZ47), luminal-binding protein 5 (BIP2; I1KPN3), chlorophyll a-b binding protein 21, chloroplastic 
(LHB1B1; P09755), chaperonin CPN60-2, mitochondrial (HSP60; I1LAL4), tubulin alpha-3 chain-like (TUA5; K7KXN7), 14-3-3-like protein D isoform X1 (AT2G42590; K7LWG5), berberine bridge enzyme-like 21 (AT4G20840; I1LOD6 and I1L0H7), succinate dehydrogenase [ubiquinone] flavoprotein subunit 1, mitochondrial (SDH1-1; 11 J8W0) and pyruvate dehydrogenase E1 component subunit alpha, mitochondrial (IAR4; I1N1B9) (Table 2).

In relation to down-accumulated proteins in PEG 6\%/control comparison, some proteins related to somatic embryogenesis development were also observed, such as cell Division cycle protein 48 homolog (ATCDC48B; P54774), 5-methyltetrahydropteroyltriglutamate-homocysteine methyltransferase (ATMS1; 11LXY2), heat shocl $70 \mathrm{kDa}$ protein (HSP70-B; A0A0R0FY49), guanosine nucleotide disphoasphate dissociation inhibitor 2 (GDI2; AOAOROK398), superoxidase dismutase [Mn], mitochondrial MSD1; I1 JYA9), pectinesterase 2 (AT2G45220; I1J7T0), glutamate decarboxylase 1 (GAD; I1JHT1), UDP-glucose 6-dehydrogenase1 (UGD2; I1LWR5), UDP-glucose6-dehydrogenase 4 (UGD2; I1J5Y9), NADP-dependent malic enzyme (NADP-ME4; I1J4J8), chaperonin CPN60-2, mitochondrial (HSP60; A0A0R4J656), glutamate dehydrogenase 1 (GDH1; Q5F2M9), fructokinase-2 isoform B (AT3G59480; I1LQD7), phosphoenolpyruvate carboxylase 2 (PPC1; Q6Q2Z8), elongation factor Tu, chloroplastic (RABE1b; A0A0R0FCD2), aminopeptidase M1 isoform X2 (APM1; I1 JTY8), sucrose synthase 2 isoform X2 (SSA; A0AOR0G163), hypersensitive-induced response protein0like protein 2 (AT1G69840; I1 LWI3), mitochondrial dicarboxylate/tricarboxylate transport DTC (AT5G19760; I1 KSD7), ATP-dependent 6phosphofructokinase 3 (PFK3; I1KV07) and, the peroxidase 16 (AT2G18980; A0AOR0GAY5) and peptidylprolyl cis-trans isomerase (ROC3; AOAOROH9T5) was unique in the control treatment (Table 2).

\section{Biological process enrichment proteins under PEG 6\%/control at 14 days of embryogenic callus maturation of P. edulis 'UENF Rio Dourado'}

The network of enriched biological processes by STRING for up-accumulated and unique proteins in PEG $6 \%$ resulted in the enrichment of the main processes, such as ATP metabolic process and glycolytic process, with proteins such as EN01, GAPCP-1, ATPB, TPI and IAR4, generation of precursor and metabolite energy with AT3G02360, AT5G59840, AT5G58330, TPI, SDH1-1, IAR4 proteins and response to light stimulus with LHB1B1 and RCA proteins (Fig. 4A; Table 2). Down-accumulated and unique proteins in embryogenic callus in the control treatment were enriched mainly for cellular metabolic processes with ATCDC48B, UGD2, NADP-ME4, PPC1 and SSA (Fig. 4B; Table 2).

Other biological processes elucidated by GO (Gene Ontology) by UniProt showed that up-regulated proteins in embryogenic callus matured in PEG 6\%, such as cell wall modification with pectinesterase protein (AT5G27870), protein folding and stress response with HSP81-3, HSP60 and HOP2, and downregulated proteins were observed in biological processes such as sucrose metabolic process (SSA), protein transport (GDI2), tricarboxylic acid cycle (PPC1) and malate metabolic process (NADP-ME4) (Table 2).

\section{Discussion}




\section{Effect of PEG on the maturation of somatic embryos and changes in PA contents}

The use of $6 \%$ PEG promoted a significantly higher number of somatic embryos at the cotyledonary stage than the control (Table 1). Similarly, the use of PEG resulted in the highest number of somatic embryos reaching the maturation phase in other species, as observed for Panax ginseng (Langhansova et al. 2004), Picea abies (Hudec et al. 2016), C. papaya (Heringer et al. 2013; Vale et al. 2018), and Texas ebony (Ibarra-López et al. 2021). PEG molecules are large and unable to pass through cell walls, which leads to a restriction of water absorption and reduced turgor pressure, reducing the intracellular osmotic potential and ultimately leading to desiccation (Misra et al. 1993; Vale et al. 2018). The effect of PEG mimics naturally occurring water stress on seeds during late stages of maturation, and the stress caused by PEG increases concentrations of $A B A$, which are essential for somatic embryo development (Stasolla and Yeung 2003; Bohanec et al. 2010). Our findings show that PEG 6\% can be an efficient treatment of the maturation process, allowing the optimization of somatic embryogenesis protocols of $P$. edulis 'UENF Rio Dourado'.

Embryogenic callus matured under PEG 6\% showed a higher proportion of compact callus, which contained MC, allowing them to be called embryogenic callus (Fig. 2). These cells are small and isodiametric, have cytoplasm-rich cells and allow the formation of somatic embryos (Fig. 2D). In contrast, the non-embryogenic portion of the callus presented elongated and highly vacuolated cells that were dispersed throughout the callus (Fig. 2D). During subculture cycles, it is possible to separate embryogenic callus from non-embryogenic callus by morphological characteristics, as shown in somatic embryogenesis in sugarcane (Silveira et al. 2013). The presence of MC and NMC cells in the same callus was previously shown for several plant systems (Fehér et al. 2003; Silveira et al. 2013), including other species of the Passifloracea family (Silva et al. 2009; Paim-Pinto et al. 2011; Silva et al. 2015). It is known that the acquisition of embryogenic competence requires the presence of non-embryogenic cells that produce and secrete molecules in the culture medium (Hecht et al. 2001). These molecules could then be perceived by other cells, which in turn could become competent and develop into somatic embryos (Pennell et al. 1992; Santa-Catarina et al. 2004; Silveira et al. 2013). In this sense, the presence of nonembryogenic cells within embryogenic callus could be relevant to the development of somatic embryos in P. edulis.

In addition to morphological changes, genetic and biochemical factors are also important for understanding somatic embryogenesis in various plant somatic cells (Karami and Saidi 2010). Among the biochemical molecules, PA content could be reported as a marker for the acquisition of somatic embryogenesis competence (Santa-Catarina et al. 2004; Silveira et al. 2013). In our study, the total free PA levels showed that PEG $6 \%$ treatment was associated with an increase in the levels of total free PAs and free Put at 28 days of the maturation process (Fig. 3). Similarly, embryogenic callus of sugarcane showed a higher level of total free PAs, which was associated with meristematic division cells and somatic embryo formation (Silveira et al. 2013). Moreover, the addition of exogenous Put in somatic 
embryogenesis of sugarcane improved the number of somatic embryos, increasing the levels of endogenous total free PAs (Reis et al. 2016). In Araucaria angustifolia, higher endogenous contents of Put were observed in embryogenic callus under prematuration treatment in culture medium containing PEG and maltose (Farias-Soares et al. 2014). In addition, a higher level of Spm was observed in embryogenic callus treated with PEG 6\% compared to the control (Fig. $3 \mathrm{C}$ ), suggesting the relevant role of Spm in the maturation of somatic embryogenesis in $P$. edulis. In embryogenic callus of sugarcane, high levels of Spm and Spd were associated with the acquisition of embryogenic competence that allows the maturation of somatic embryos (Silveira et al. 2013). Further studies on the exogenous addition of PAs in the maturation process of $P$. edulis 'UENF Rio Dourado' embryogenic callus should be developed to verify the effects of exogenous PAs on somatic embryo maturation and development.

\section{Effect of PEG $6 \%$ on the differential accumulation of proteins during the maturation of somatic embryos}

The use of proteomics as a tool for understanding biochemical and molecular aspects has been important in the study of somatic embryogenesis (Campos et al. 2017; Heringer et al. 2018). Comparative proteomic analysis between embryogenic callus treated with PEG $6 \%$ and control treatments was performed in $P$. edulis cv 'UENF Rio Dourado', and the results are discussed based on the DAPs and unique proteins and their relationship with somatic embryogenesis development.

\section{ATP metabolic process, glycolytic process and generation of precursor metabolite energy}

The glycolytic process has been considered a central process in the development of somatic embryos and seeds in different species, especially in the maturation process (Carrari and Fernie 2006; Fait et al. 2006; Xu et al. 2012; Ge et al. 2014). We identified several glycolytic proteins unique to PEG $6 \%$ treatment or up-accumulated in embryogenic callus at 14 days of maturation with PEG $6 \%$ compared to the control treatment, such as EN01, GAPCP-1, ATPB, TPI and IAR4, which modulate the glycolytic pathway.

In glycolysis, plant cells modify carbohydrates in energy by ATP, which is essential to generate intermediate metabolites that modulate the biosynthesis of molecules at the intra- and extracellular levels required by cells (Aguilar-Hernández and Loyola-Vargas 2018). During developmental processes the cell requires a greater energy supply for the new formation of embryos, and the proteins of the glycolytic pathway are associated with the development of somatic embryos and embryogenic competence in different species, such as sugarcane (Heringer et al. 2015), Zea mays (Varhaníková et al. 2014) and C. papaya (Vale et al. 2014; Almeida et al. 2019).

In our study, the TPI protein was identified as a unique PEG $6 \%$ treatment. This glycolytic enzyme is essential for glycolysis, mainly for energy generation (Zhou et al. 2009; Zhao et al. 2015). The TPI enzyme was identified as a protein associated with the initial stages of somatic embryo formation in embryogenic callus (Xu et al. 2012; Zhao et al. 2015; Almeida et al. 2019) and in response to PEG treatments in the maturation process (Vale et al. 2014). 


\section{Response to light stimulus}

In our study, we identified proteins related to photosynthesis biological processes in embryogenic callus at 14 days of maturation under PEG 6\% (Fig. 4), including two proteins, RCA and LHB1B1 (Unique Peg $6 \%$ ) (Table 2; Fig. 4A). The initial differentiation of photosynthetic tissues during somatic embryogenesis seems to be associated with coordinated expression of mRNA for $r b c L$, Ihcb and por in late torpedoshaped embryos (Sato-Nara et al. 2004). Thus, the photosynthesis-related proteins that differentially accumulated in embryogenic callus matured under PEG $6 \%$ compared with the control treatment were relevant for photosynthetic apparatus differentiation.

\section{Response to stress-related proteins and Protein Folding}

The network process identified HOP2, HSP81-3 and HSP60 as up-regulated proteins that are related to the stress response. The stress response is a recurrent common protein group that is regulated in embryogenic cultures and is associated with the induction of somatic embryo formation (Heringer et al.). As PEG acts as an osmotic agent that causes osmotic stress, the identification of up-regulated proteins could be associated with the stress response in embryogenic callus of $P$. edulis treated with PEG $6 \%$. Stress response proteins are frequently reported in dividing cells or tissues, among which heat-shock proteins (HSPs) were found to be most representative in embryogenic callus (Zhao et al. 2015). HSP proteins have also been identified during somatic embryogenesis of Vitis vinifera (Zhang et al. 2009), C. papaya (Vale et al. 2014), sugarcane (Reis et al. 2016), Larix principis-rupprechtii (Zhao et al. 2015) and $A$. angustifolia (Fraga et al. 2016). In this sense, the increase in the accumulation of HSP proteins in embryogenic callus of $P$. edulis treated with PEG suggests the relevance of these proteins for maturation processes in this species.

Another protein that was unique in Peg 6\% was 14-3-3 protein (AT2G42590; K7LWG5) (Table 2). The 14-33 protein is a highly conserved phosphoserine/phosphothreonine-binding protein that regulates a wide range of target proteins in all eukaryotes and may play important roles in the response to environmental, metabolic and nutritional stresses (Roberts et al. ; Zhao et al. 2015).

Working with embryogenic and non-embryogenic tissues of price rupprecht's larch (Larix principisrupprechtii), regulation of ATP synthases by the 14-3-3 protein was observed, suggesting a mechanism for plant cells to adapt to environmental changes such as nutrient supply, especially exogenous plant growth regulators, during somatic embryogenesis (Zhao et al. 2015).

\section{Up-accumulated proteins related to cell wall modification}

During the transition of somatic embryos from embryogenic callus of Manihot esculenta several expression genes was involved in the polysaccharide hydrolase of the cell wall and pectinesterase precursors (Ma et al. 2015). Pectinesterases proteins are enzymes responsible for breaking the glycosidic bond of pectin substances in the cell wall through hydrolysis (Kohli et al. 2015; Kumaravel et al. 2020) and can catalyze the de-esterification of pectin to form a pectate gel (Micheli 2001; Ma et al. 2015). In addition, pectinesterase enzymes can act to loosen the cell wall by pectin degradation, and influence cell 
expansion during the maturation of somatic embryos (Kumaravel et al. 2020). In our work, we observed that one pectinesterase (AT5G27870; 11 KMW7) up-accumulated in embryogenic callus treated with PEG $6 \%$ compared with the control treatment, suggesting its involvement in the development of somatic embryos during the maturation process, possibly by modulating biosynthesis and cell wall expansion.

\section{Cellular metabolic process}

Among the DAPs, some proteins related to cellular metabolic processes, such as ATCDC48B, UGD2, NADP-ME4, PPC1 and SSA, were down-regulated in embryogenic callus incubated with PEG $6 \%$ compared to the control treatment (Table 2; Fig. 4B). PPC1 is an enzyme with increased abundance mainly in zygotic embryo formation (Chollet et al. 1996) and catalyzes phosphoenolpyruvate to yield oxaloacetate (OAA)(Chollet et al. 1996). These enzymes were related to photosynthesis, but in the last decade, the higher number of studies showing PPC1 also increased abundance in non-photosynthetic conditions, especially in seeds, because these enzymes use $\mathrm{HCO}_{3}^{-}$liberated by respiration to yield oxaloacetate, which is converted into aspartate, malate and other intermediates of the TCA cycle(Leblová et al. 1991; Golombek et al. 1999; O'Leary et al. 2011; Noah et al. 2013). In general, the higher levels of the TCA cycle and oxidative phosphorylation enzymes in somatic embryos suggest a more active aerobic/respiration pathway (Noah et al. 2013).

In our study, PPC1 was down-accumulated in embryogenic callus matured under PEG 6\% compared with the control treatment, suggesting that this enzyme may modulate the conversion of oxaloacetate in intermediates of the TCA cycle and may capture the energy necessary for the development of somatic embryos.

In the future, metabolic studies are recommended to verify whether the presence and absence of PEG $6 \%$ can cause a higher level of the intermediates of the TCA cycle that is related to cellular respiration because we now verify that PPC1 may be an indication that in the absence of PEG $6 \%$ treatment, the embryogenic callus may be performing more cellular respiration to produce energy to form somatic embryos than with PEG treatment in P. edulis 'UENF Rio Dourado'.

\section{Conclusion}

The use of PEG 6\% promoted the maturation of somatic embryos of $P$. edulis 'UENF Rio Dourado', significantly increasing the number of somatic embryos at the globular and cotyledonary stages compared to the control treatment. The addition of PEG $6 \%$ significantly increased the endogenous contents of Spm in embryogenic callus, which was related to the effect of PEG treatment on the development of somatic embryos during the maturation process. Embryogenic callus treated with PEG $6 \%$, when compared to the control, showed an up-accumulation of proteins related to glycolytic processes and responses to light stimulus, which are necessary for somatic embryo development. This is the first report showing somatic embryo development for $P$. edulis 'UENF Rio Dourado'.

\section{Declarations}


Funding for this work was provided by the Conselho Nacional de Desenvolvimento Científico e Tecnológico (CNPq) (307755/2019-3) and the Fundação Carlos Chagas Filho de Amparo à Pesquisa do Estado do Rio de Janeiro (FAPERJ) (Proc E26/211.690/2015; Proc E26/203.311/2017, E26/200.999/2021). This study was also financed in part by the Coordenação de Aperfeiçoamento de Pessoal de Nível Superior - Brazil (CAPES) - Finance Code 001. KZ is thankful for the scholarship funding provided by CAPES. FAA, EMV, NB, RGV and RCS acknowledge scholarship funding from FAPERJ.

\section{Data availability}

The mass spectrometry proteomics data have been deposited to the ProteomeXchange Consortium via the PRIDE partner repository with the dataset identifier PXD031175. The list of all identified proteins is available in the supplementary material.

\section{Financial interests}

The authors declare they have no financial interests.

\section{Conflicts of interest/Competing interests}

The authors have no conflicts of interest to declare that they are relevant to the content of this article.

\section{Authors' contribution}

$\mathrm{KZ}$ and VS designed the research; KZ, NB and EMV conducted the experiment. KZ, FAA and EMV carried out the proteomics and statistical analyses; KZ, RGV and CS-C performed the histomorphological analysis; KZ, RGV and RCS performed the PA analysis. All the authors read, reviewed and approved the manuscript.

\section{References}

1. Aguilar-Hernández V, Loyola-Vargas VM (2018) Advanced proteomic approaches to elucidate somatic embryogenesis. Front Plant Sci 9:1658. https://doi.org/10.3389/fpls.2018.01658

2. Alkhateeb A (2006) Somatic embryogenesis in date palm (Phoenix dactylifera L.) cv. Sukary in response to sucrose and polyethylene glycol. Biotechnology 5:466-470.

https://doi.org/10.3923/biotech.2006.466.470

3. Almeida FA, Vale EM, Reis RS, Santa-Catarina C, Silveira V (2019) LED lamps enhance somatic embryo maturation in association with the differential accumulation of proteins in the Carica papaya L.'Golden'embryogenic callus. Plant Physiol Biochem 143:109-118.

https://doi.org/10.1016/j.plaphy.2019.08.029

4. Anthony P, Otoni W, Power JB, Lowe KC, Davey MR (1999) Protoplast isolation, culture, and plant regeneration from Passiflora. In: Hall H (ed) Plant Cell Culture Protocols. Humana Press, Totowa, pp 169-181. https://doi.org/10.1385/1-59259-583-9:169 
5. Bernacci LC, Meletti LMM, Soares-Scott MD, Passos IRS, Junqueira NTV (2005) Espécies de maracujá: caracterização e conservação da biodiversidade. In: Faleiro FG, Junqueira NTV, Braga MF (eds) Maracujá: Germoplasma e Melhoramento Genético, vol 1. Embrapa, Brasília, pp 559-586

6. Bohanec B, Vinterhalter B, Cingel A (2010) Effect of activated charcoal, abscisic acid and polyethylene glycol on maturation, germination and conversion of Aesculus hippocastanum androgenic embryos. Afr J Biotechnol 9:3786-3793

7. Botini N, Almeida FA, Cruz KZCM, Reis RS, Vale EM, Garcia AB, Santa-Catarina C, Silveira V (2021) Stage-specific protein regulation during somatic embryo development of Carica papaya L.'Golden'. Biochimica et Biophysica Acta (BBA)-Proteins and Proteomics 1869:140561. https://doi.org/10.1016/j.bbapap.2020.140561

8. Campos NA, Panis B, Carpentier SC (2017) Somatic embryogenesis in coffee: the evolution of biotechnology and the Integration of omics technologies offer great opportunities. Front Plant Sci 8:1-12. https://doi.org/10.3389/fpls.2017.01460

9. Carrari F, Fernie AR (2006) Metabolic regulation underlying tomato fruit development. J Exp Bot 57:1883-1897. https://doi.org/10.1093/jxb/erj020

10. Chollet R, Vidal J, O'Leary MH (1996) Phospho enol pyruvate carboxylase: a ubiquitous, highly regulated enzyme in plants. Annu Rev Plant Biol 47:273-298.

https://doi.org/https://doi.org/10.1146/annurev.arplant.47.1.273

11. Distler U, Kuharev J, Navarro P, Levin Y, Schild H, Tenzer S (2014a) Drift time-specific collision energies enable deep-coverage data-independent acquisition proteomics. Nat Methods 11:167-170. https://doi.org/10.1038/nmeth.2767

12. Distler U, Kuharev J, Navarro P, Levin Y, Schild H, Tenzer S (2014b) Drift time-specific collision energies enable deep-coverage data-independent acquisition proteomics. Nat Methods 11:167. https://doi.org/10.1038/nmeth.2767

13. https://www.nature.com/articles/nmeth.2767\#supplementary-information

14. Distler U, Kuharev J, Navarro P, Tenzer S (2016) Label-free quantification in ion mobility-enhanced data-independent acquisition proteomics. Nat Protoc 11:795-812. https://doi.org/10.1038/nprot.2016.042

15. Dodeman VL, Ducreux G, Kreis M (1997) Zygotic embryogenesis versus somatic embryogenesis. J Exp Bot 48:1493-1509. https://doi.org/10.1093/jxb/48.8.1493

16. Fait A, Angelovici R, Less H, Ohad I, Urbanczyk-Wochniak E, Fernie AR, Galili G (2006) Arabidopsis seed development and germination is associated with temporally distinct metabolic switches. Plant Physiol 142:839-854. https://doi.org/10.1104/pp.106.086694

17. Faleiro FG, Junqueira NTV, Junghans TG, Jesus ONd, Miranda D, Otoni WC (2019) Advances in passion fruit (Passiflora spp.) propagation. Revista Brasileira de Fruticultura 41. https://doi.org/10.1590/0100-29452019155

18. Farias-Soares FL, Steiner N, Schmidt ÉC, Pereira ML, Rogge-Renner GD, Bouzon ZL, Floh ES, Guerra MP (2014) The transition of proembryogenic masses to somatic embryos in Araucaria angustifolia 
(Bertol.) Kuntze is related to the endogenous contents of IAA, ABA and polyamines. Acta Physiologiae Plantarum 36:1853-1865. https://doi.org/10.1007/s11738-014-1560-6

19. Fehér A, Pasternak TP, Dudits D (2003) Transition of somatic plant cells to an embryogenic state. Planr Cell Tissue Organ Cult 74:201-228. https://doi.org/10.1023/A:1024033216561

20. Fraga HPF, Vieira LN, Heringer AS, Puttkammer CC, Silveira V, Guerra MP (2016) DNA methylation and proteome profiles of Araucaria angustifolia (Bertol.) Kuntze embryogenic cultures as affected by plant growth regulators supplementation. Plant cell, Tissue and Organ Culture 125:pp. 353-374. https://doi.org/10.1007/s11240-016-0956-y

21. Ge X, Zhang C, Wang Q, Yang Z, Wang Y, Zhang X, Wu Z, Hou Y, Wu J, Li F (2014) iTRAQ protein profile differential analysis between somatic globular and cotyledonary embryos reveals stress, hormone, and respiration involved in increasing plantlet regeneration of Gossypium hirsutum L. J Proteome Res 14:268-278. https://doi.org/10.1021/pr500688g

22. Golombek S, Heim U, Horstmann C, Wobus U, Weber H (1999) Phosphoenolpyruvate carboxylase in developing seeds of Vicia faba L.: gene expression and metabolic regulation. Planta 208:66-72. https://doi.org/https://doi.org/10.1007/s004250050535

23. Hecht V, Vielle-Calzada J-P, Hartog MV, Schmidt ED, Boutilier K, Grossniklaus U, de Vries SCJPP (2001) The Arabidopsis SOMATIC EMBRYOGENESIS RECEPTOR KINASE 1 gene is expressed in developing ovules and embryos and enhances embryogenic competence in culture. Plant Physiol 127:803-816. https://doi.org/10.1104/pp.010324

24. Heringer AS, Barroso T, Macedo AF, Santa-Catarina C, Souza GHMF, Floh EIS, de Souza-Filho GA, Silveira $V(2015)$ Label-free quantitative proteomics of embryogenic and non-embryogenic callus during sugarcane somatic embryogenesis. PLoS ONE 10:23.

https://doi.org/10.1371/journal.pone.0127803

25. Heringer AS, Santa-Catarina C, Silveira V (2018) Insights from proteomic studies into plant somatic embryogenesis. Proteomics 18:1700265. https://doi.org/10.1002/pmic.201700265

26. Heringer AS, Vale EM, Barroso T, Santa-Catarina C, Silveira V (2013) Polyethylene glycol effects on somatic embryogenesis of papaya hybrid UENF/CALIMAN 01 seeds. Theoretical and Experimental Plant Physiology 25:116-124. https://doi.org/10.1590/S2197-00252013000200004

27. Hudec L, Konrádová H, Hašková A, Lipavská H (2016) Norway spruce embryogenesis: changes in carbohydrate profile, structural development and response to polyethylene glycol. Tree Physiol 36:548-561. https://doi.org/10.1093/treephys/tpw016

28. Ibarra-López A, del Carmen Ojeda-Zacarías M, Lozoya-Saldaña H, Vázquez-Alvarado RE, OlivaresSáenz E, Treviño-Ramírez JE (2021) In vitro somatic embryogenesis of Texas ebony (Ebenopsis ebano [Berland.] Barneby \& JW Grimes). In Vitro Cellular \& Developmental Biology-Plant:1-12. https://doi.org/10.1007/s11627-021-10170-8

29. Produção agrícola Permante - (2020) (2020) https://cidades.ibge.gov.br/brasil/pesquisa/15/0? ano $=2020$. Accessed 25-10-2021 
30. Isah T (2019) Proteome study of somatic embryogenesis in Nothapodytes nimmoniana (J. Graham) Mabberly. 3 Biotech 9:1-23. https://doi.org/10.1007/s13205-019-1637-4

31. Karami O, Saidi A (2010) The molecular basis for stress-induced acquisition of somatic embryogenesis. Mol Biol Rep 37:2493-2507. https://doi.org/10.1007/s11033-009-9764-3

32. Kohli P, Kalia M, Gupta R (2015) Pectin methylesterases: a review. Journal of Bioprocessing \& Biotechniques 5:1. https://doi.org/10.4172/2155-9821.1000227

33. Kumaravel M, Uma S, Backiyarani S, Saraswathi MS (2020) Proteomic analysis of somatic embryo development in Musa spp. cv. Grand Naine (AAA). Sci Rep 10:1-12. https://doi.org/10.1038/s41598020-61005-2

34. Langhansova L, Konradova H, Vaněk T (2004) Polyethylene glycol and abscisic acid improve maturation and regeneration of Panax ginseng somatic embryos. Plant Cell Rep 22:725-730. https://doi.org/10.1007/s00299-003-0750-2

35. Leblová S, Strakošová A, Vojtěchová M (1991) Regulation of the activity of phosphoenolpyruvate carboxylase isolated from germinating maize (Zea mays $\mathrm{L}$.) seeds by some metabolites. Biol Plant 33:66-74. https://doi.org/https://doi.org/10.1007/BF02873790

36. Ma Q, Zhou W, Zhang P (2015) Transition from somatic embryo to friable embryogenic callus in cassava: dynamic changes in cellular structure, physiological status, and gene expression profiles. Front Plant Sci 6:824. https://doi.org/10.3389/fpls.2015.00824

37. Márquez-Martín B, Sesmero R, Quesada MA, Pliego-Alfaro F, Sánchez-Romero C (2011) Water relations in culture media influence maturation of avocado somatic embryos. J Plant Physiol 168. https://doi.org/10.1016/j.jplph.2011.06.008. :2028-2034

38. Micheli F (2001) Pectin methylesterases: cell wall enzymes with important roles in plant physiology. Trends Plant Sci 6:414-419. https://doi.org/10.1016/s1360-1385(01)02045-3

39. Mishra S, Sanyal I, Amla D (2012) Changes in protein pattern during different developmental stages of somatic embryos in Chickpea. Biol Plant 56:613-619. https://doi.org/10.1007/s10535-012-01240

40. Misra S, Attree S, Leal I, Fowke L (1993) Effect of abscisic acid, osmoticum, and desiccation on synthesis of storage proteins during the development of white spruce somatic embryos. Ann Botany 71:11-22. https://doi.org/10.1006/anbo.1993.1002

41. Nakayama F (1966) Cultivo in vitro de tejidos de Passiflora caerulea. Revista de la Facultad de Agronomía de la Universidad Nacional de La Plata 42:63-74

42. Nanjo Y, Skultety L, Uvackova L, Klubicova K, Hajduch M, Komatsu S (2012) Mass spectrometrybased analysis of proteomic changes in the root tips of flooded soybean seedlings. J Proteome Res 11:372-385. https://doi.org/10.1021/pr200701y

43. Noah AM, Niemenak N, Sunderhaus S, Haase C, Omokolo DN, Winkelmann T, Braun H-P (2013) Comparative proteomic analysis of early somatic and zygotic embryogenesis in Theobroma cacao L. J Proteom 78:123-133. https://doi.org/10.1016/j.jprot.2012.11.007 
44. O'Leary B, Park J, Plaxton WC (2011) The remarkable diversity of plant PEPC (phosphoenolpyruvate carboxylase): recent insights into the physiological functions and post-translational controls of nonphotosynthetic PEPCs. Biochem J 436:15-34. https://doi.org/https://doi.org/10.1042/BJ20110078

45. Otoni W, Blackhall N, Vaz FdU, Casali V, Power J, Davey M (1995) Somatic hybridization of the Passiflora species, $P$. edulis f. flavicarpa Degener. and $P$. incarnata L. Journal of Experimental Botany 46:777-785. https://doi.org/10.1093/jxb/46.7.777

46. Otoni W, Paim Pinto D, Rocha D, Vieira L, Dias L, Silva ML, Silva CV, Lani ERG, Silva LC, Tanaka FAO (2013) Organogenesis and Somatic Embryogenesis in Passion fruit Passiflora sps. In: Aslam J, Srivastava OS, Sharma MP (eds) Somatic Embryogenesis and Gene Expression, vol 1. edn. Narosa Publishing House, New Delhi, pp 1-17

47. Ozarowski M, Thiem B (2013) Progress in micropropagation of Passiflora spp. to produce medicinal plants: a mini-review. Revista Brasileira de Farmacognosia 23:937-947.

https://doi.org/10.1590/S0102-695X2013000600011

48. Paim-Pinto DL, de Almeida AMR, Rêgo MM, da Silva ML, de Oliveira EJ, Otoni WC (2011) Somatic embryogenesis from mature zygotic embryos of commercial passionfruit (Passiflora edulis Sims) genotypes. Plant Cell, Tissue and Organ Culture 107:521-530. https://doi.org/10.1007/s11240-0110003-y

49. Pal Bais H, Ravishankar GA (2002) Role of polyamines in the ontogeny of plants and their biotechnological applications. Planr Cell Tissue Organ Cult 69:1-34. https://doi.org/10.1023/A:1015064227278

50. Pennell RI, Janniche L, Scofield GN, Booij H, de Vries SC, Roberts K (1992) Identification of a transitional cell state in the developmental pathway to carrot somatic embryogenesis. J Cell Biol 119:1371-1380. https://doi.org/10.1083/jcb.119.5.1371

51. Perez-Riverol Y, Csordas A, Bai J, Bernal-Llinares M, Hewapathirana S, Kundu DJ, Inuganti A, Griss J, Mayer G, Eisenacher M (2019) The PRIDE database and related tools and resources in 2019: improving support for quantification data. Nucleic Acids Res 47:442-450. https://doi.org/10.1093/nar/gky1106

52. Prudente DO, Paiva R, Carpentier S, Swennen R, Nery FC, Silva LC, Panis B (2017) Characterization of the formation of somatic embryos from mature zygotic embryos of Passiflora ligularis Juss. Plant Cell, Tissue and Organ Culture 131:97-105. https://doi.org/10.1007/s11240-017-1266-8

53. R Core Team (2014) R : A language and environment for statistical computing. R Foundation for Statistical Computing, Vienna, Austria. http://www.R-project.org/

54. Reis RS, de Moura Vale E, Heringer AS, Santa-Catarina C, Silveira V (2016) Putrescine induces somatic embryo development and proteomic changes in embryogenic callus of sugarcane. $\mathrm{J}$ Proteom 130:170-179. https://doi.org/10.1016/j.jprot.2015.09.029

55. Reis RS, Vale EM, Sousa KR, Santa-Catarina C, Silveira V (2021) Pretreatment free of 2, 4dichlorophenoxyacetic acid improves the differentiation of sugarcane somatic embryos by affecting 
the hormonal balance and the accumulation of reserves. Planr Cell Tissue Organ Cult 145:101-115. https://doi.org/10.1007/s11240-020-01995-z

56. Roberts MR, Salinas J, Collinge DB (2002) 14-3-3 proteins and the response to abiotic and biotic stress. Plant Mol Biol 50:1031-1039. https://doi.org/https://doi.org/10.1023/A:1021261614491

57. Rosa YBCJ, Aizza LCB, Armanhi JSL, Dornelas MC (2013) A Passiflora homolog of a D-type cyclin gene is differentially expressed in response to sucrose, auxin, and cytokinin. Planr Cell Tissue Organ Cult 115:233-242. https://doi.org/10.1007/s11240-013-0355-6

58. Salo HM, Sarjala T, Jokela A, Häggman H, Vuosku J (2016) Moderate stress responses and specific changes in polyamine metabolism characterize scots pine somatic embryogenesis. Tree Physiol 36:392-402. https://doi.org/10.1093/treephys/tpv136

59. Santa-Catarina C, Olmedo AD, Meyer GD, Macedo J, de Amorim W, Viana AM (2004) Repetitive somatic embryogenesis of Ocotea catharinensis Mez. (Lauraceae): effect of somatic embryo developmental stage and dehydration. Plant Cell Tissue and Organ Culture 78:55-62. https://doi.org/10.1023/B:TICU.0000020395.40974.8a

60. Santa-Catarina C, Silveira V, Balbuena TS, Viana AM, Estelita MEM, Handro W, Floh EIS (2006) IAA, ABA, polyamines and free amino acids associated with zygotic embryo development of Ocotea catharinensis. Plant Growth Regul 49:237-247. https://doi.org/10.1007/s10725-006-9129-z

61. Sato-Nara K, Demura T, Fukuda H (2004) Expression of photosynthesis-related genes and their regulation by light during somatic embryogenesis in Daucus carota. Planta 219:23-31. https://doi.org/10.1007/s00425-003-1201-6

62. Shannon P, Markiel A, Ozier O, Baliga NS, Wang JT, Ramage D, Amin N, Schwikowski B, Ideker T (2003) Cytoscape: a software environment for integrated models of biomolecular interaction networks. Genome Res 13:2498-2504. https://doi.org/10.1101/gr.1239303

63. Silva GM, Cruz ACF, Otoni WC, Pereira TNS, Rocha DI, Silva ML (2015) Histochemical evaluation of induction of somatic embryogenesis in Passiflora edulis Sims (Passifloraceae). In Vitro Cellular \& Developmental Biology-Plant 51:539-545. https://doi.org/10.1007/s11627-015-9699-4

64. Silva JC, Gorenstein MV, Li G-Z, Vissers JP, Geromanos SJ (2006) Absolute quantification of proteins by LCMSE: a virtue of parallel MS acquisition. Molecular \& Cellular Proteomics 5:144-156. https://doi.org/10.1074/mcp.M500230-MCP200

65. Silva ML, Pinto DLP, Guerra MP, Floh EIS, Bruckner CH, Otoni WC (2009) A novel regeneration system for a wild passion fruit species Passiflora cincinnata Mast. based on somatic embryogenesis from mature zygotic embryos. Planr Cell Tissue Organ Cult 99:47-54. https://doi.org/10.1007/s11240009-9574-2

66. Silveira V, Floh EIS, Handro W, Guerra MP (2004) Effect of plant growth regulators on the cellular growth and levels of intracellular protein, starch and polyamines in embryogenic suspension cultures of Pinus taeda. Plant Cell, Tissue and Organ Culture 76:53-60.

https://doi.org/10.1023/A:1025847515435 
67. Silveira V, Vita AM, Macedo AF, Dias MFR, Floh EIS, Santa-Catarina C (2013) Morphological and polyamine content changes in embryogenic and non-embryogenic callus of sugarcane. Planr Cell Tissue Organ Cult 114:351-364. https://doi.org/10.1007/s11240-013-0330-2

68. Stasolla C, Yeung EC (2003) Recent advances in conifer somatic embryogenesis: improving somatic embryo quality. Planr Cell Tissue Organ Cult 74:15-35. https://doi.org/10.1023/A:1023345803336

69. Tautorus TE, Fowke LC, Dunstan DI (1991) Somatic embryogenesis in conifers. Can J Bot 69:18731899. https://doi.org/10.1139/b91-237

70. Vale EM, Heringer AS, Barroso T, da Silva Ferreira AT, da Costa MN, Perales JEA, Santa-Catarina C, Silveira V (2014) Comparative proteomic analysis of somatic embryo maturation in Carica papaya L. Proteome Science 12:37. https://doi.org/10.1186/1477-5956-12-37

71. Vale EM, Reis RS, Passamani LZ, Santa-Catarina C, Silveira V (2018) Morphological analyses and variation in carbohydrate content during the maturation of somatic embryos of Carica papaya. Physiology and Molecular Biology of Plants 1-11. https://doi.org/10.1007/s12298-017-0501-4

72. Varhaníková M, Uvackova L, Skultety L, Pretova A, Obert B, Hajduch M (2014) Comparative quantitative proteomic analysis of embryogenic and non-embryogenic calli in maize suggests the role of oxylipins in plant totipotency. J Proteom 104:57-65.

https://doi.org/10.1016/j.jprot.2014.02.003

73. Viana AP, Gonçalves GM, Silva MGdM, Ferreira RT, Pereira TNS, Pereira MG Amaral Júnior ATd, Carvalho GFd (2016) UENF Rio Dourado: a new passion fruit cultivar with high yield potential.Crop Breeding and Applied Biotechnology16:250-253. https://doi.org/10.1590/1984-70332016v16n3c38

74. Wisniewski JR, Zougman A, Nagaraj N, Mann M (2009) Universal sample preparation method for proteome analysis. Nat Methods 6:359-362. https://doi.org/10.1038/nmeth.1322

75. Xu H, Zhang W, Gao Y, Zhao Y, Guo L, Wang J (2012) Proteomic analysis of embryo development in rice (Oryza sativa). Planta 235:687-701. https://doi.org/10.1007/s00425-011-1535-4

76. Yadav JS, Rajam MV (1997) Spatial distribution of free and conjugated polyamines in leaves of Solanum melongena $\mathrm{L}$. associated with differential morphogenetic capacity: efficient somatic embryogenesis with putrescine. J Exp Bot 48:1537-1545. https://doi.org/10.1093/jxb/48.8.1537

77. Zhang J, Ma H, Chen S, Ji M, Perl A, Kovacs L, Chen S (2009) Stress response proteins' differential expression in embryogenic and non-embryogenic callus of Vitis vinifera L. cv. Cabernet Sauvignon - a proteomic approach. Plant Sci 177:103-113. https://doi.org/10.1016/j.plantsci.2009.04.003

78. Zhao J, Wang B, Wang X, Zhang Y, Dong M, Zhang J (2015) iTRAQ-based comparative proteomic analysis of embryogenic and non-embryogenic tissues of Prince Rupprecht's larch (Larix principisrupprechtii Mayr). Planr Cell Tissue Organ Cult 120:655-669. https://doi.org/10.1007/s11240-0140633-y

79. Zhou S, Sauve R, Thannhauser TW (2009) Aluminum induced proteome changes in tomato cotyledons. Plant Signal Behav 4:769-772. https://doi.org/10.1093/jxb/erp065

\section{Figures}



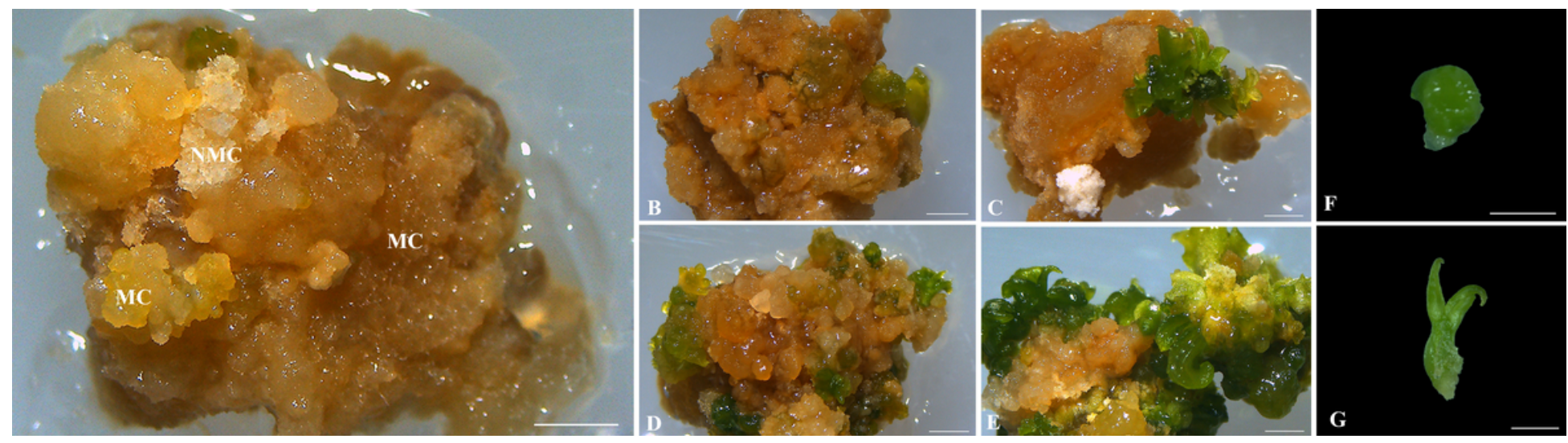

\section{Figure 1}

Morphological aspects of embryogenic callus of $P$. edulis 'UENF Rio Dourado' during maturation. A) embryogenic callus before maturation treatments on control and PEG 6\%; B) embryogenic callus with 14 days under control treatment showing green points in the surface of callus; $\mathbf{C}$ ) embryogenic callus with 28 days under control treatment showing somatic embryos at the cotyledonary stage; D) embryogenic callus with 14 days under PEG $6 \%$ treatment showing green points at the surface, and somatic embryos in the globular stage (arrow); E) embryogenic callus with 28 days under PEG $6 \%$ treatment with somatic embryos in the globular and cotyledonary stage; F) globular somatic embryo; $\mathbf{G}$ ) cotyledonary somatic embryo; Bars: (A-E) 0.1 mm; (F-G) 0.2 mm.
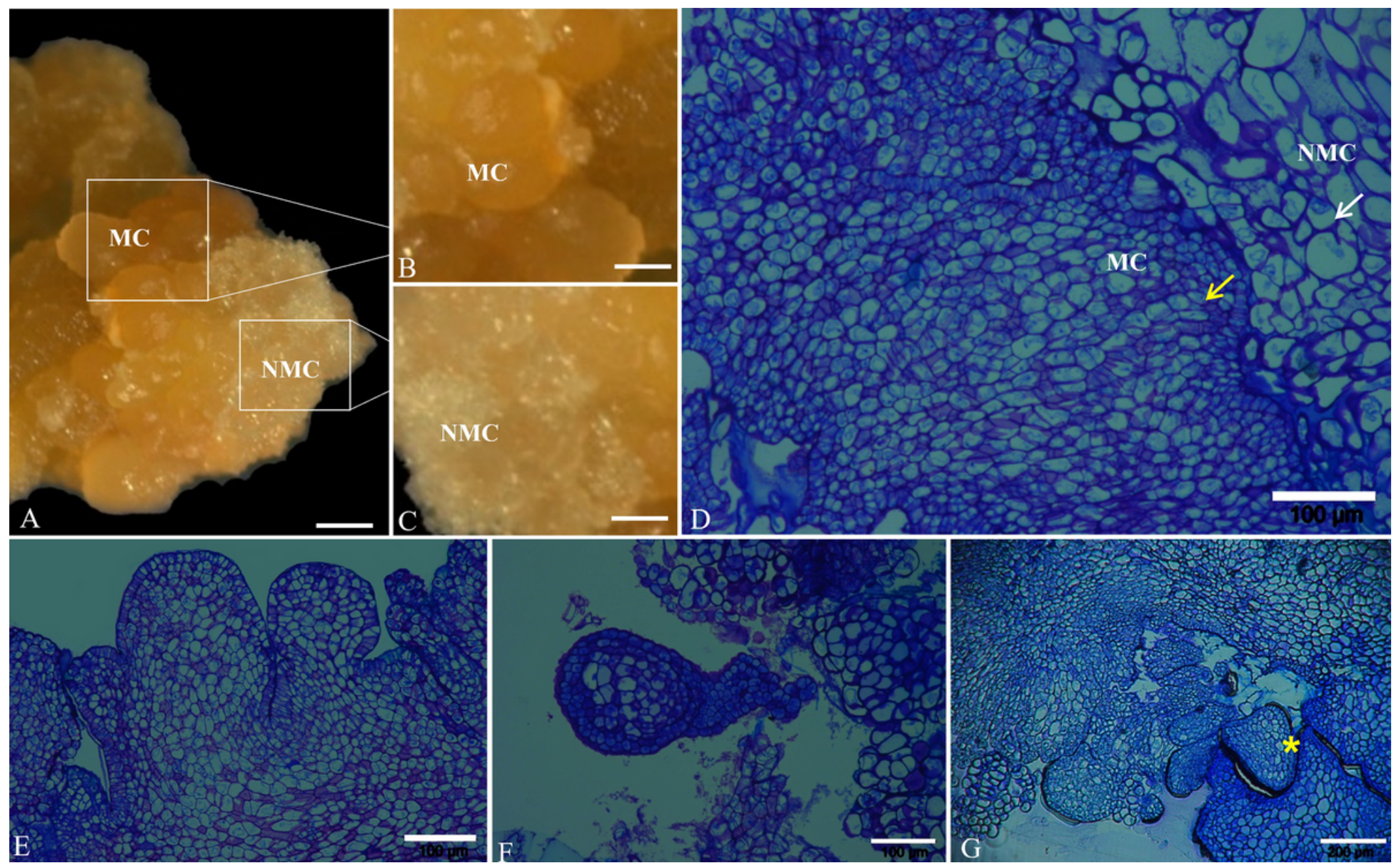
Figure 2

Morphological and histomorphological aspects of $P$. edulis embryogenic callus matured under $6 \%$ PEG at 14 days. A) Embryogenic callus showing both meristematic type cells (MC) and nonmeristematic-type cells (NMC); B) MC; C) NMC; D) histomorphology of embryogenic callus showing MC (yellow arrow) and NMC (white arrow) portions. E) embryogenic callus showing the MC from which the somatic embryos differentiate in the periphery of the callus; $\mathbf{F}$ ) globular somatic embryo; $\mathbf{G}$ ) heart somatic embryo (yellow asterisk).
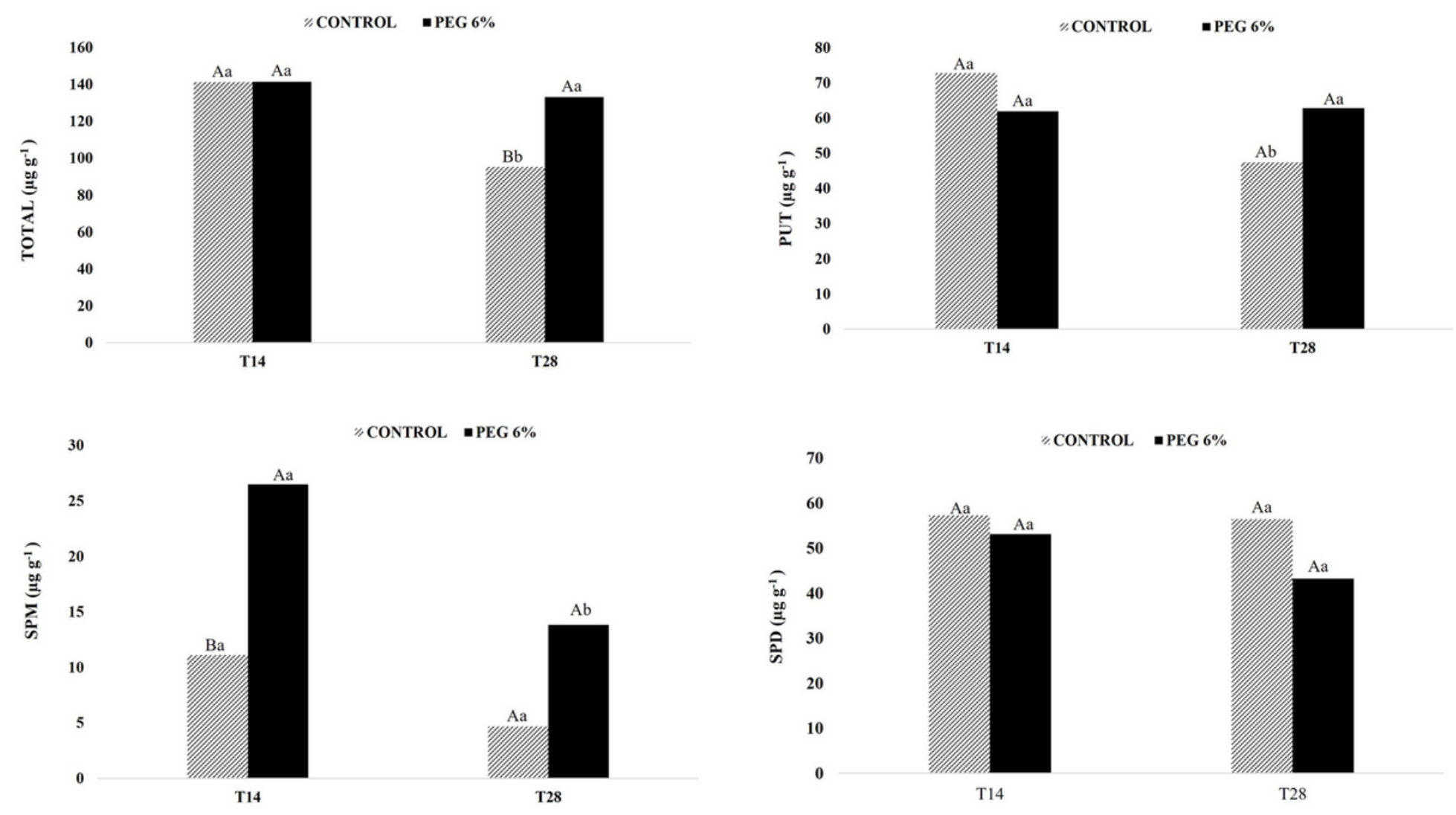

\section{Figure 3}

Endogenous contents of free PAs in embryogenic callus of $P$. edulis 'UENF Rio Dourado' at 14 and 28 days of maturation under control (without PEG) and PEG 6\% treatments. A) Total PAs; B) Put; C) Spm; D) Spd. Capital letters denote significant differences between PEG treatments for each day of incubation. Lowercase letters denote significant differences between days of incubation in the same maturation treatment. Means followed by different letters are significantly different according to the StudentNewman-Keuls (SNK) test $(p<0.05) ;\left(n=3 ; \mathrm{CV}_{\text {Total }}=10.63 \% ; \mathrm{CV}_{\text {Put }}=15.60 \% ; \mathrm{CV}_{\mathrm{Spm}}=38.93 \% ; \mathrm{CV}_{\mathrm{Spd}}=\right.$ $18.12 \%$;). 
Glycolytic process, ATP metabolic process

ENO1, GAPCP-1, PB, TPI, IAR4

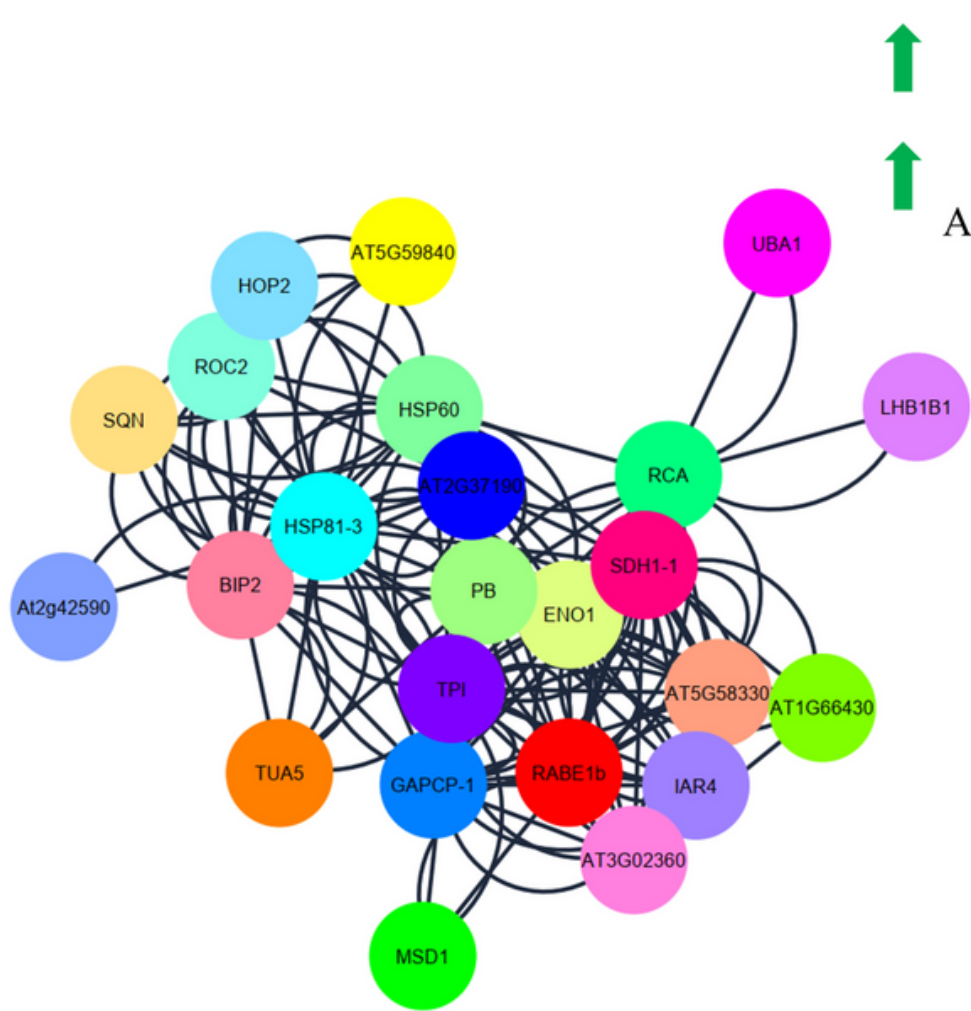

Generation of precursor and metabolites energy

AT3G02360, AT5G59840, AT5G58330, TPI, SDH1-1, IAR4

Response to light stimulus

LHB1B1, RCA

B

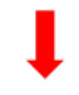

Cellular metabolic process

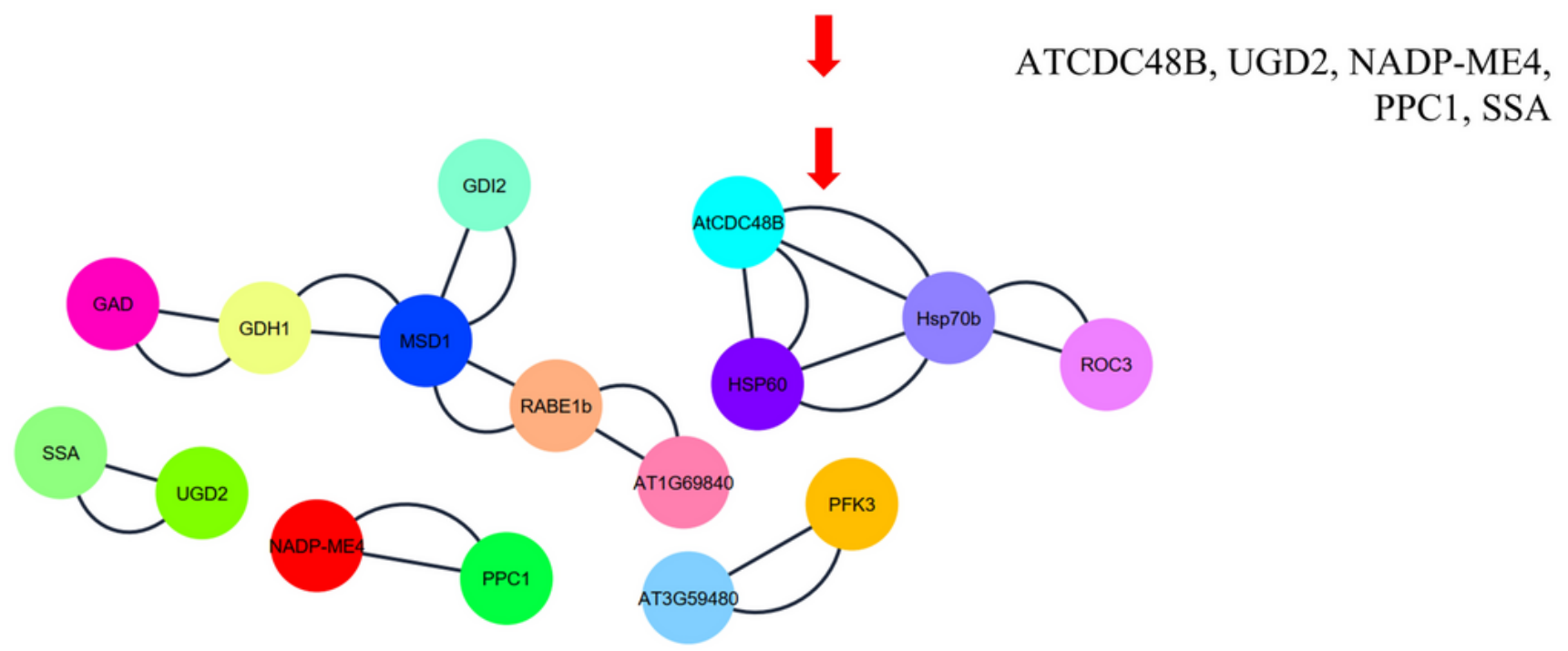

Figure 4

Protein-protein interaction network between DAPs of embryogenic callus of $P$. edulis 'UENF Rio Dourado' at 14 days of maturation under PEG $6 \%$ compared to those from the control treatment. A) Upaccumulated proteins in PEG6\%/control and unique proteins in PEG 6\% treatment. B) Down-regulated proteins in PEG 6\%/control and unique proteins in the control treatment. Green arrows indicate the biological process that increased in up-accumulated proteins, and red arrows indicate the biological 
process that decreased in down-accumulated proteins. The analysis was performed using $A$. thaliana orthologs identified by STRING using Cytoscape. 